Journal Plus Education, ISSN: 1842-077X, E-ISSN (online) 2068-1151 Vol XIX (2018), No. 1. pp. 103-115

\title{
THE RELATIONSHIP BETWEEN THE TYPES OF COMMUNICATION OF THE TEACHER AND THE RESULTS IN THE LEARNING OF THE STUDENTS, ON THE INTERNALITY-EXTERNAL DIMENSION
}

\author{
Evelina BALAŞ, Ph.D., \\ „Aurel Vlaicu" University of Arad, PhD \\ evelinabalas@yahoo.com
}

Abstract: The quality of the communication processes within the class depends on both the teacher and the students, in either case both being responsible for optimizing and stimulating classroom communication. The teacher, however, has primarily the responsibility to develop the classroom's communication environment, which is about informational and interpersonal exchange between teacher-student, student-teacher, teacher-class, class-teacher, student-student. Thus, we aim in this study for the determination of the factors that contribute to the use of a means of communication within the class, focusing on the dimension of internality - externality of the personality of the teaching staff and the students.

Key words: teacher; beliefs; students; educational communication; personality;

\section{Introduction}

Educational communication supports the achievement of the educational act as a whole, regardless of its contents, levels, forms or partners involved in the process. We can center this communication on acquiring knowledge, skills and attitudes, we can do it through various forms, formal or informal.

Inter-human communication activity, when is properly taught, manifests itself in concrete ways, taking into account content, intentions and functions. Such aommunication maybe: communication through language; nonverbal communication through symbols, visual communication, paraverbal communication.

Each teacher has certain beliefs and concepts about the class of students, on how it should be run and organized. Many studies have been developed on the management of the class of students (Dan Potolea, Emil Paun, Romita Iucu, Ioan Jinga Elena Joita, Emil Stan, Cătălina Ulrich, etc.), 
all underlining the idea that the teacher as a school manager has to constantly focus his attention on the learner, the student. In the relationship of influencing students through communication, the teacher can exert constructive role behaviors that have a positive impact, destructive that have a negative impact and neutral that does not have a real impact on the target or receiver. Teachers' intentions and behavioral influences can easily be traced to successfully completing or failing student activity. The communicative style of the teacher, his or her way of communicating with the pupils is often reflected, as Liliana Ezekil (2002, p.155) puts it, in: the quality of the student classroom interactions the teacher manages; receptivity to the pupil as an interlocutor; the way the teacher facilitates students' process of receiving, understanding, processing messages; the way the teacher directs and controls the process of creating messages by students; the way student-student communication is stimulated; what the professor thinks about effective communication; what the teacher values in his interaction with students.

A subtle but effective form of social-educational influence that teachers use in teacher-student communication is persuasion. In this context, persuasion aims to determine the receiver, the person or the group to change attitudes and behaviors, unforced by others. Unlike the socio-educational influences and the messages communicated by the teacher in the didactic situation, students can adopt positive, negative or neutral attitudes. To have an attitude towards something or someone, it is foremost about reacting affectively, evaluating the stimulus with positive or negative emotions, and secondly the attitudes always have a behavioral component that predisposes the subjects to act in a certain way towards the object that influences them and, last but not least, a strong, cognitive component, because what the person feels about an object depends, to a certain extent, on her views about that stimulus.

We must also take into account the fact that communication is a fundamental component of psychosocial interaction; it is a continuous exchange of different messages between teachers and students, meant to achieve a sustainable inter-human relationship, to influence the continuation or modification of individual or group behavior.

Thus, in the present study, we have tried to determine the factors that contribute to the selection of a means of communication within the class, focusing on the classroom's style of leadership, on the internality-externality dimension of the personality of both the teacher and the students, the length of service of the teachers and the class they are working with.

We started from the hypothesis that there are significant differences in the appreciation of the teacher's communication style, between the students with good learning outcomes and those with poor results. 


\section{Methodology}

To test this hypothesis, we compiled a sample of 46 teachers with a work experience of between 12 and 36 years. We mention that the teachers come from 27 schools in Arad County and the approach for collecting their answers was the participation in a training course, which demonstrates a common point, namely the valorization of the continuous learning and the awareness that there will always be an aspect which needs to be improved. It is worthwhile to investigate why this aspect should not even be the educational communication.

As far as student selection is concerned, the initial task of teachers was to indicate the best and the lowest student in the class according to the average grades to date. Through this we have tried to eliminate the subjectivity in choice and preferences for certain students. We consider that this task has been efficiently achieved, given the significant statistically differences between the group of good students and weak students. Further on, the survey was based on the confirmation of the teachers and the selected students were questioned for data collection.

\section{Tools and working procedure}

Rotter's locus of internal-external control survey (1966). Rotter believes that the fundamental dimension of the personality that influences daily behaviors is the way the person perceives the source of recompense (positive reinforcement) or sanctions (negative reinforcement), that is, how he establishes the link between this system and his own behavior. It demonstrates the existence of two categories of individuals: those who believe that positive or negative reinforcements derive directly from their own actions and those who believe that those reinforcements depend on external forces independent of their mode of action. The first category of subjects, including those who consider themselves responsible for everything that happens to them, has an internal locus of control, and the second category of people who identify the source of events as external have an external locus of control. Thus, Rotter considers the internality-externality combo, a fundamental dimension of personality, a significant variable in the behavior of a person.

A person who believes that the success or failure of his/her actions in different social actions is due to his or her own person (skills, experience, voluntary effort or their absence) has an internal control, assuming responsibility for their actions and consequences. Such a person will have a tendency to repeat this behavior in similar situations. On the other hand, a person who attributes the causes of his successes or failures to external aspects has an external control, with a lower responsibility for his own 
actions. Research reveals interpersonal differences about the level of external or internal control of personality due to different ways of attributing the causes of one's behavior or the behavior of others.

To measure the fundamental dimension of the personality - external and internal control - Rotter developed the questionnaire for the assessment of the locus of control. The test contains 29 items, for the teachers the variant a), b) was applied, and for the students the "yes", "no" option was applied. The training for the Rotter questionnaire consisted in circling the variant with which they agree from two variants a) or b), which allows differentiation between internal and external. As far as the students are concerned, they were asked to answer "yes" or "no" to the 29 items of the questionnaire, the completion of the questionnaire being accompanied by explanations and clarifications, where appropriate.

\section{Results}

The study on communication in the class of students was based on a correlational experiment. The investigated subjects were divided into three experimental groups: teachers, good students and weak students, and the descriptive statistics are presented in Table 1. The data collection tools were presented in the study methodology, and what is also worth mentioning is that the pupils have been given a version of the locus of control scale customized on the age of the group.

The correlations sought were between: a) locus of control and the way of communication, the leadership style of teachers, and b) locus of control and appreciation of the educational communication by the good and the weak students.

The average marker of educational communication demonstrates that bilaterality is the way of communication characteristic of the sample of teachers, with a standard deviation of only 0.37 compared to that. The marker of locus of control for teachers, according to the sampling: 0-13 internal and 13-23 external, falls within the limits of externalism, average $=$ 15.48. This means that the questioned teachers have external factors as a way of interpreting the causality of the events. The average marker of the leadership style for teachers is 1.91 and the standard deviation is 0.41 , which demonstrates the participatory way in conducting educational activities. The low standard deviation shows that this style is a representative feature of the sample.

We can see that the appreciation of educational communication in good students differs from that of students with poor results in class. Good students consider that the teacher communication's style is bilateral, average 2.33 with a standard deviation of 0.60 , while weak students deem a unilateral communication, average 1.35, standard deviation of 0.48 . 
The marker locus of control - good and weak students, again registers differences. If the good students have a locus of internal control, the average of 11.65 (limits 0-13), we cannot say the same about weak students, which are characterized by a locus of external control, the average 16.15 (limits 1323). This means that the questioned weak students have external factors as a means of interpreting the causality of events, and good students give priority to internal factors.

By switching to the statistical data for the sample of students, we may notice a qualitative difference of hetero-appreciation on the marker of the educational communication, both towards the teacher and within the sample, between the good and the weak learners. It is noticed that the percentage of unilateralism is kept constant, 6.5\%, which shows the accuracy and convergence of opinions regarding this rather negative aspect of the educational process, namely, the one-way communication, from teacher to student. The proportions in the appreciation of the bilateral and educational style are also maintained. The conclusion is that the type of educational communication in the case of good students denotes facilitating aspects, that the students appreciate this dimension correctly, the influence of the style of communication on the good pupils having a positive impact.

Figure 1 presents graphically the frequencies of hetero-appreciation of educational communication in good students

Figure 1 - The frequencies of hetero-appreciation of educational communication in good students

aprecierea comunicarii educationale la elevii buni

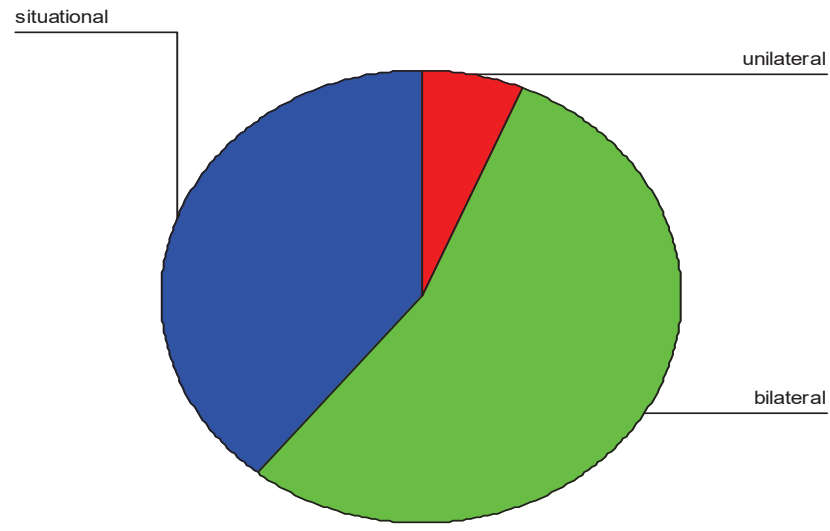


However, we cannot say the same thing about the opinion of weak students. The appreciation of this category of subjects differs significantly from both teacher self-appreciation and the appreciation of the good students in learning. There is no case in which a poor student appreciates the teacher in terms of bilaterality. A very high percentage of $65 \%$ (compared to $6.5 \%$ for both teachers and students) considers that the teacher is unilateral. The appreciation may be subjective if we consider the previous correspondence, but it can be true if the relationship of the teacher with the weak learners is customized, based on a directed communication in which reprimand prevails. This aspect is worth exploring in a future study.

The $16 \%$ percentage, which considers the teacher to be situational in communication, may have to do with to the fact that weak students feel ignored during classroom activities, focusing on them only on homework evaluation and assessments. Of course, there is also an explanation that "He has something with me", which again demonstrates possible discrimination within the class.

Figure $2-$ The frequencies of hetero-appreciation of educational communication in weak students

aprecierea comunicarii educationale la elevii slabi

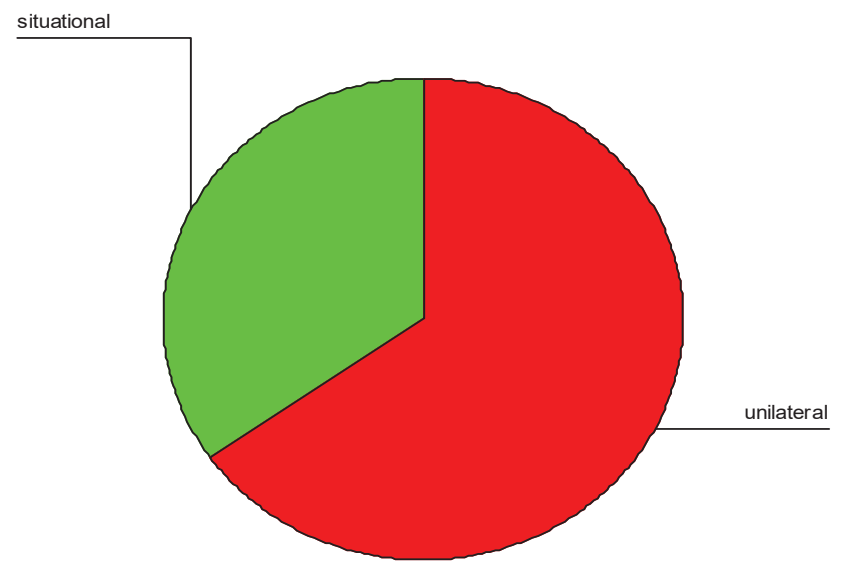

The fundamental dimension of personality that influences everyday behaviors and implicitly educational behavior is how the person perceives the source of recompense or sanctions, that is, how he/she establishes the link between this system and his/her own behavior. The internalityexternality dimension of personality becomes a significant variable of a person's behavior, influencing the way the teacher attaches the causes of his 
successes and failures either to internal factors (dispositional assumption) or to external factors (situational assumption).

Figure 3 shows the distribution of teachers on this dimension. The fact that teachers are $84.8 \%$ external is a good thing from the perspective of getting in touch with good students.

Table 1 -Locus of control marker in teachers

\begin{tabular}{|c|c|c|c|c|}
\hline $\begin{array}{c}\text { Locus of control } \\
\text { teachers }\end{array}$ & SCORE & $\begin{array}{c}\text { Frequenc } \\
\mathbf{y}\end{array}$ & $\begin{array}{c}\text { Percentage } \\
\mathbf{\%}\end{array}$ & $\begin{array}{c}\text { Cumulative } \\
\text { percentage } \%\end{array}$ \\
\hline \multirow{3}{*}{ INTERNAL } & 9 & 2 & 4.3 & 4.3 \\
\cline { 2 - 5 } & 11 & 3 & 6.5 & 10.9 \\
\cline { 2 - 5 } & 13 & 2 & 4.3 & 15.2 \\
\hline \multirow{5}{*}{ EXTERNAL } & 14 & 11 & 23.9 & 39.1 \\
\cline { 2 - 5 } & 15 & 6 & 13.0 & 52.2 \\
\cline { 2 - 5 } & 16 & 4 & 8.7 & 60.9 \\
\cline { 2 - 5 } & 17 & 8 & 17.4 & 78.3 \\
\cline { 2 - 5 } & 18 & 3 & 6.5 & 84.8 \\
\cline { 2 - 5 } & 19 & 4 & 8.7 & 93.5 \\
\cline { 2 - 5 } & 20 & 2 & 4.3 & 97.8 \\
\cline { 2 - 5 } & 21 & 1 & 2.2 & 100.0 \\
\cline { 2 - 5 } & Total & 46 & 100.0 & \\
\hline
\end{tabular}

This means that teachers attribute the cause of school success, to students' own resources, and they only intervene by directing activity to achieve goals. However, when dealing with weak learners, it is not a positive thing, because there is no question of the effectiveness of their own educational communication. School failure is attributed to situational factors, namely student resources.

The percentage of $15.2 \%$ of internal teachers is a guarantee of awareness of their own limitations in the educational process, which optimizes learning. It would be preferable for teachers to have a higher level of internality in order to be able to effectively ignore the interference of subjectivism, which inevitably appears in the assessment of students. 
Figure 3 - Teachers distribution on the locus of control marker locus of control invatatori

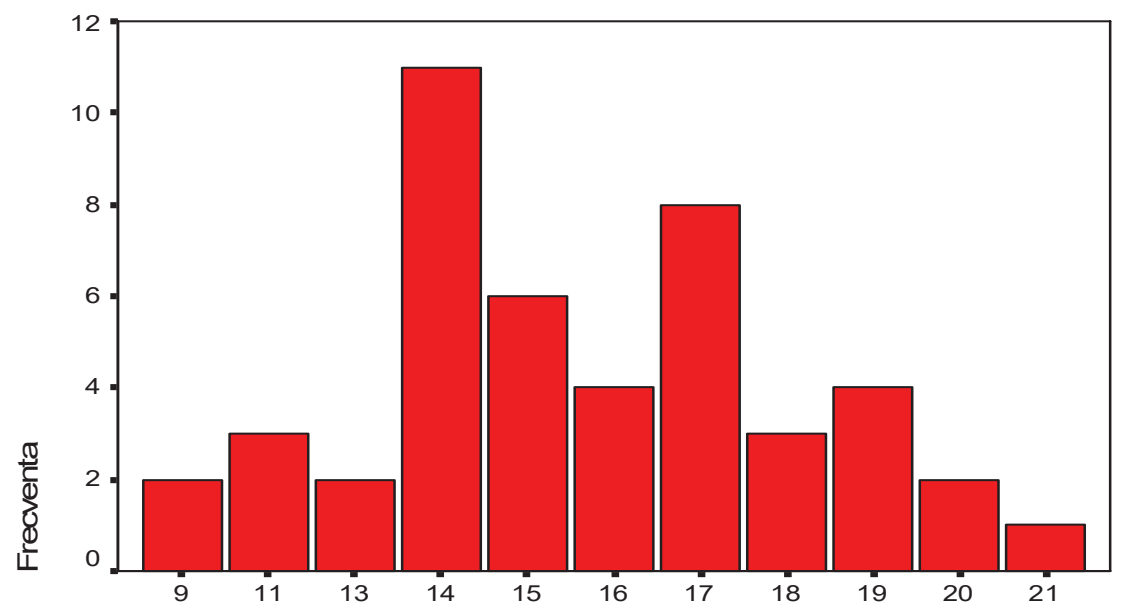

locus of control invatatori

Switching to the sample of students, it is worth mentioning that Schopler and Layton (1975), studying success and school failure, demonstrate that teachers tend to explain school failure through internal dispositional factors rather than external factors and school success through situational factors. As a way of protecting one's self, a poor student will

\begin{tabular}{|c|c|c|c|c|}
\hline $\begin{array}{c}\text { Locus of } \\
\text { control good } \\
\text { students }\end{array}$ & SCORE & Frequency & Percentage\% & $\begin{array}{c}\text { Cumulative } \\
\text { Percentage\% }\end{array}$ \\
\hline \multirow{4}{*}{ INTERNAL } & 8 & 4 & 8.7 & 8.7 \\
\cline { 2 - 5 } & 9 & 7 & 15.2 & 23.9 \\
\cline { 2 - 5 } & 10 & 4 & 8.7 & 32.6 \\
\cline { 2 - 5 } & 11 & 7 & 15.2 & 47.8 \\
\cline { 2 - 5 } & 12 & 7 & 15.2 & 63.0 \\
\hline \multirow{5}{*}{ EXTERNAL } & 13 & 7 & 15.2 & 78.3 \\
\cline { 2 - 5 } & 14 & 5 & 10.9 & 89.1 \\
\cline { 2 - 5 } & 16 & 2 & 4.3 & 93.5 \\
\cline { 2 - 5 } & 17 & 1 & 4.3 & 97.8 \\
\cline { 2 - 5 } & Total & 46 & 100.0 & 100.0 \\
\hline
\end{tabular}

Table 2 - The locus of control marker in good students 
Indicate external causes related to the teacher, school failure, and similarly, a good student will indicate internal causes to school success, thus reinforcing self-esteem. This is an explanation for the fact that $78.3 \%$ of the good students have a locus of internal control and $91.3 \%$ of the weak students are external.

Table 3 - The locus of control marker in weak students

\begin{tabular}{|c|c|c|c|c|}
\hline $\begin{array}{c}\text { Locus of } \\
\text { control weak } \\
\text { students }\end{array}$ & SCORE & Frequency & Percentage\% & $\begin{array}{c}\text { Cumulative } \\
\text { Percentage } \\
\%\end{array}$ \\
\hline \multirow{4}{*}{ INTERNAL } & 9 & 1 & 2.2 & 2.2 \\
\cline { 2 - 5 } & 10 & 1 & 2.2 & 4.3 \\
\cline { 2 - 5 } & 11 & 1 & 2.2 & 6.5 \\
\hline \multirow{5}{*}{ EXTERNAL } & 13 & 4 & 8.7 & 15.2 \\
\cline { 2 - 5 } & 14 & 6 & 13.0 & 28.3 \\
\cline { 2 - 5 } & 15 & 5 & 10.9 & 39.1 \\
\cline { 2 - 5 } & 16 & 4 & 8.7 & 47.8 \\
\cline { 2 - 5 } & 17 & 8 & 17.4 & 65.2 \\
\cline { 2 - 5 } & 19 & 4 & 17.4 & 82.6 \\
\cline { 2 - 5 } & 20 & 2 & 8.7 & 91.3 \\
\cline { 2 - 5 } & 21 & 2 & 4.3 & 95.7 \\
\cline { 2 - 5 } & Total & 46 & 100.0 & 100.0 \\
\hline
\end{tabular}

Figure 4 and Figure 5 show the frequencies distributed by the weak and good students, on the locus of control.

Figure 4 - Distribution of good students on the locus of control marker 
locus of control elevi buni

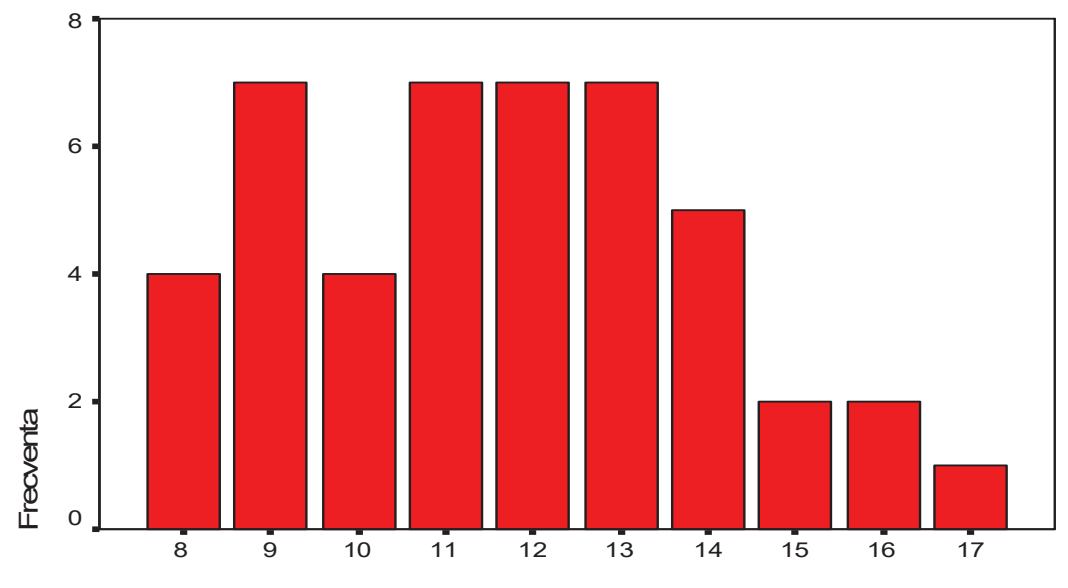

locus of control elevi buni

Figure 5 - Distribution of weak students on the locus of control marker

locus of control elevi slabi

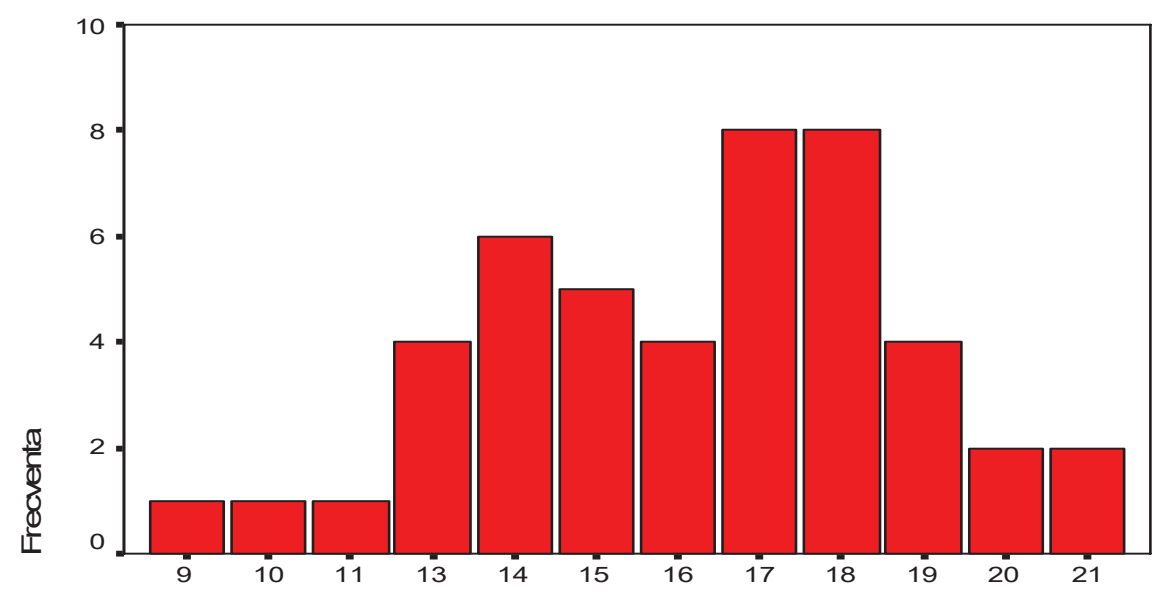

locus of control elevi slabi

By placing the respondents' results on the marker locus of control on a scale, we can assume that good students are $78.3 \%$ internal, followed by teachers, $15.2 \%$ and weak students, $8.7 \%$. This is positive thing from the point of view of the teacher-student relationship, given that during the succession of the primary education, pupils form certain capacities and personality traits that will further on influence adult life. 
Journal Plus Education, ISSN: 1842-077X, E-ISSN (online) 2068-1151 Vol XIX (2018), No. 1. pp. 103-115

\section{Discussions}

The correlations obtained are significant at a threshold of $\mathrm{p}<0.05$ and 0.01 and we will analyze each one to see if the assumptions made are validated.

1 .

Educational communication correlates positively significantly with the locus of teacher control, 0.376 at a threshold $\mathrm{p}$ $<0.05$. This means that the more internal the teachers are, the more bilateral the communication is and at a higher degree of externality, the teachers are more unilateral in the way of communication. An internal locus of control implies giving preference to its own provisions, a deeper awareness of its own competencies and limits, a facilitating context for active listening, which makes the communicative process a bidirectional act. An external locus of control causes the causal attributions of educational processes to be external, the teacher considering that he cannot do much to change the course of the events, placing the responsibility on the student. In this case the communication becomes unilateral, the teacher giving the tasks without taking into account the feedback from the students.

2. There is a significantly positive correlation between the educational communication and its perception by the weak pupils at learning 0.379 at a threshold $\mathrm{p}<0.01$. This demonstrates the impact of the style of communication on weak learners.

3. There is a significant negative correlation of -0.568 at a threshold $p$ $<0.01$ between the locus of control of the weak students and the appreciation of the educational communication. The higher the degree of internality of the weak student, the more unidirectional the teacher will be in communication, and the more external the weaker pupil is, he will appreciate the educational communication as more permissive.

4. There is a significant negative correlation between the locus of control of good students and the appreciation of their educational communication -0.600 to a threshold $\mathrm{p}<0.01$. The more internal a good student is, valuing dispositional factors, the higher the bilateral quality of communication will be. Being in a higher position than other colleagues, the teacher will pay more attention to him, which will lead to greater confidence in his abilities, courage in addressing the homework and lowering school failures. The more external the good student is, the more situational the communication will be, considering that its success is due to the situational factors. This is the case for a good student who was taken by surprise with a poorprepared lesson, received a weak grade, but not as bad as another student who is considered poor at learning. 


\section{Conclusions}

The hypothesis that there are significant differences in the appreciation of the teacher's communication between pupils with good learning outcomes and poor pupils has been confirmed in the sense that good students perceive the teacher as bidirectional, paying attention and taking into account their opinions, and students with poor learning outcomes perceive the teacher (in a large percentage) as unidirectional. This may be due to the fact that in the didactic activity, the teacher, concerned with the curriculum, does not always have time or does not give time for the individualization of learning, the students with poor results considering themselves neglected, forgotten, putting the cause of their failure on the teacher. This is also explained by the results obtained in the Locus of Control questionnaire, which shows that a poor student attributes external causes, such as teacher, to school failure and similarly, a good student attributes internal causes to school success, reinforcing his self-esteem.

Good students tend to give internal causes to all school events because they are successful in this area, which is why they will be more appreciative of teacher competence. That is why they consider teachers as bilateral in their relationship with them. They perceive the way of teaching more as a guide, positively appreciating it and overlapping it to the style of educational communication. Because school failure is low, they benefit only from positive reinforcements, which leads to the appreciation of the leadership style as a communication. On the other hand, poor students at school, due to school failure, have developed an external way of assigning the cause, namely considering that someone else is responsible for their poor grades. This person will of course be the teacher, who in this group of subjects is considered unilateral and situational.

The educational communication greatly influences the educational process and pupils' performance in school tasks, which is demonstrated by the difference in perception between good and weak students. Their perception should be similar since the task concerns the evaluation of the same person, the teacher. The teacher can also contribute to deforming the perception of educational communication if he relies heavily on reprimand for weak students and on praise for good students.

Two-way communication should play the leading role, and it should not make any difference between students. It has been demonstrated by the Pygmalion effect that a negative perception of a student's ability will ultimately lead to a decrease in performance, and they will only try to meet that expectations. Also, the effect is true in the opposite direction, a weaker student being stimulated to learn when the teacher's expectations about his intellectual resources increase. 
In the communication relationship between the transmitter and receiver there are a series of psychological, social and cultural-professional characteristics that differentiate them and which relate to the personality and education of each one, the different social status of the teacher and the pupil, their different representations, from the different field of experience to each other.

\section{References}

Abric, J.C., (2002), Psihologia comunicării. Teorii şi metode, Ed. Polirom, Iaşi

Anghel, P., (2003), Stiluri şi metode de comunicare, Ed. Aramis, Bucureşti

Duck, S., (2000), Relaţiile interpersonale, Ed. Polirom, Iaşi

Dumitru, I. Al., (2000), Dezvoltarea gândirii critice şi învăţarea eficientă, Ed. De Vest, Timişoara

Ezechil, L., (2002), Comunicarea educaţională în context şcolar, EDP, Bucureşti

Iucu, R., (2000), Managementul şi gestiunea clasei de elevi. Fundamente teoretico-metodologice, Ed. Polirom, Iaşi

Pânişoară, I.O., (2003), Comunicarea eficientă. Metode de interacţiune educaţională, Ed. Polirom, Iaşi

Peretti, de A., Legrand, J.A., Boniface, J.,(trad), (2000), Tehnici de comunicare, Ed. Polirom, Iaşi

Rotter J.B. (1990). Internal Versus External Control of Reinforcement: A Case History of a Variable, American Psychologist, April 1990, 490-493

Rotter, J. B. (1992). Some comments on the "cognates of personal control." Applied \& Preventive Psychology, 1, 127-129 